\title{
Necropolitics, State of Exception, and Violence Against Indigenous People in the Amazon Region During the Bolsonaro Administration*
}

\author{
Pedro Rapozo ${ }^{1}$ \\ https://orcid.org/0000-0003-3843-5811 \\ 1Universidade do Estado do Amazonas, Manaus/AM, Brazil
}

This study presents a reflection on violence and socioenvironmental conflicts in indigenous territories in the Brazilian Amazon based on policies implemented during the Bolsonaro administration. It adopts an approach based on the statistical description of the data. In 'Amazônia Legal' violence against indigenous peoples and their territories has been marked by the consequences of economic development policies and the capitalist reappropriation of nature. State inefficiency in recognizing the territorial rights of indigenous peoples, even when the latter establish forms of (re)existing marked by political mobilizations, has led in recent years to multiple forms of violence evidenced in the violation of human rights, the state of exception, and the submission of life to the power of death.

Keywords: Brazilian Amazon; socio-environmental conflicts; indigenous peoples; violence; necropolitics; state of exception.

http://doi.org/10.1590/1981-3821202100020003

Correspondence: phrapozo@uea.edu.br

This publication is registered under a CC-BY Licence.

\footnotetext{
*The reflections of this study are part of ongoing research funded by the Research Support Foundation for the State of Amazonas (FAPEAM) and the National Council for Scientific and Technological Development (CNPq) and and it will be published in academic outlets.
} 
$\mathrm{T}$ he Brazilian Amazon and its first peoples were never immune to the globalization processes of the capitalist economy worldwide and its violent consequences. As a 'territory', historically present as a reserve of national and international value, it has sometimes been seen as an invented 'Eldorado', sometimes as an idyllic paradise represented by the modern myth of untouched nature, also metamorphosized by the antonyms of 'progress' and 'civilization'. These processes, implemented in a discourse of demographic 'vacuum', put in place economic regimes of nationalization, expressed in developmental policies marked by distinct processes of the exploitation of natural resources and forming fronts for agricultural expansion following a narrative of the Amazon as 'the final frontier' to be conquered and occupied in the twentieth and twenty-first centuries.

The trajectory of this process ignored (and still ignores) the knowledge produced about, by, and for the Amazon, as well as obscuring the presence of the first peoples who inhabited it, imposing a socially exclusionary model of social, political, and economic organization on their territories and the knowledge contained in them. These elements are marked by numerous situations of violation of human rights against these peoples. One of its current expressions is in the institutionalization of violence ${ }^{1}$, understood here by the ideas of 'necropolitics' and 'state of exception' attributed to the philosophers Joseph-Achille Mbembe (2003) and Giorgio Agamben (2004), who although they present a profound reflection on the state and the violence expressed in the wars and dictatorial systems of the twentieth century, demonstrate how in times of crisis the exercise of the monopoly of violence is expressed in the power of those who dictate the consequences of life and death, as part of a set of social control policies.

Both authors have developed a fundamental understanding of the state and contemporary politics, since by putting law and democracy in question they present a reflection of the legitimation of violence, as well as impunity and the suspension

\footnotetext{
${ }^{1}$ Studies of violence, in its multiple interpretations, conflicts, and ethnic groups, can reveal a path to a profound understanding of the issue in question. However, without any intention of drafting a theory of violence and social conflicts, I will advise interested readers interested in deepening this reflection to consult the work of Adorno (1999), Barreira (2008), Bourdieu (1989), Elias and Scotson (1965), Giddens and Held (1982), Hawkins (1995), Ianni (2004), Machado (2008), Misse (2006), Santos (2009), and Wacquant (2000).
} 
of rights, expressed in a narrative of the sovereign state and the concentration of political power.

In the Brazilian Amazon, this process has simultaneously led to 'epistemicides' and 'ecocides' expressed in environmental and economic policies implemented by the Brazilian government against indigenous peoples, their territories and knowledge. Evidence for this can be found, for example, in the favoring of large economic development enterprises and the marketized appropriation of nature as a value reserve, or also in the absence of policies for territorial protection and the maintenance of the modes of living of traditional peoples. In the last instance, they are revealed as the consequence of the socioenvironmental conflicts materialized by the institutionalized violence of 'state actions' (BOURDIEU, 2014).

In recent years economic development programs and the fronts of expansion of agri-business have gained space. These still propel in the twenty-first century a discourse of demographic emptiness and the neo-colonist necessity for the occupation and integration of the Amazonian geopolitical frontiers (BECKER, 2004; IANNI, 1979; PICOLI, 2006; RAPOZO and SILVA, 2020).

The political events which led to the coup and removal of President Dilma Rousseff, the subsequent Michel Temer administration, and the ascension in 2018 of the Jair Bolsonaro administration resulted from the strengthening of the extreme right conservative political mobilization which consolidated the conditions for the establishment of strategic economic interests, including those linked to the strengthening of agri-business.

A consequence of this are the current rates of deforestation, violence, and conflicts in the rural Amazonian world. Although in previous governments this information was also concerning, the increased violation of indigenous peoples' rights has become latent, revealing itself to be an extermination project in the middle of the economic and political crisis established in the current government.

As an object of discussion, we will present an analysis and reflection on the violation of human rights and threats to indigenous territories expressed in the typification of violence in the Brazilian Amazon, which occurred between the transition process of the Michel Temer administration and the Jair Bolsonaro administration in 2019. The analysis starts by considering the 
evident increments, compared to previous administrations, in the data released by research observatories and non-governmental organizations, demonstrating that significant changes are underway in Brazilian socioenvironmental policy and in the threat to the rights of indigenous people.

We present the concept of 'state of exception' and 'necropolitics' as deliberate policy options for the restriction and violation of human rights expressed in the negligence of and contempt for ethnic minorities as neocolonialist practices in the current federal administration. The analysis is restricted to descriptive statistics, obtained from secondary sources, about the occurrence of violence against indigenous peoples between 2018 and 20192; statistics examined from a perspective of qualitative interpretation (MARTINS, 2004). Although violence against indigenous peoples is expressed in numerous Brazilian territories marked by impunity, inequality, and socio-economic vulnerabilities, I particularly analyze data registered in 'Amazônia Legal' (the official Amazon region), whose socio-environmental and ethnic particularities cover the states of Amazonas (AM), Amapá (AP), Maranhão (MA), Mato Grosso (MT), Pará (PA), Rondônia (RO), Roraima (RR), and Tocantins (TO).

\section{Let the cattle herd pass: environmental policies and the violation of indigenous territories in Amazônia Legal}

The occurrence of violence motivated by the advance of productive systems, mega-ventures, and networks of illegality and criminality in the twentyfirst century reveal the dynamics of capitalism in the Amazon region and its impacts on the transformation of the means of life, the permanence and survival of indigenous peoples and their territories. However, in recent years we have seen the deliberate absence of governmental policies committed to the resolution of these problems, as well as the evident collusion of strategic interests with the productive sectors of agri-business. The result of this process can be measured by

\footnotetext{
${ }^{2}$ The significant work of the Indigenous Missionary Council (CIMI) and the Pastoral Land Commission (CPT) should be emphasized. Both publish annually reports on violence in the rural world against people and traditional communities. These reports are important in the reflections presented here and reveal the capacity of non-governmental social ventures which operate in partnerships with political mobilization and with civil society and social movements.
}

$$
\text { (2021) } 15(2) \quad \text { e0002-4/25 }
$$


the socio-environmental consequences caused by the fragility of the environmental policies adopted by the current government.

Combined with these events are the impacts resulting from deforestation and consequently fires ${ }^{3}$ which, compared to previous years, resulted in the significant loss of biodiversity all over the country. The Amazonian biome was most impacted by the fires during the first year of Bolsonaro's mandate, with a total of 89,176 foci in total, corresponding to $30 \%$ more than registered in previous years ${ }^{4}$.

The data presented by the National Institute of Spatial Research (INPE, 2019) also revealed that in 2019, in the Amazon region alone, 38\% of fires occurred in indigenous territories, with a total of 6293 foci. Analyzed comparatively, this percentage represents, solely in relation to indigenous territories, a $67 \%$ increase in reference to previous data (3758 fires in 2018 and 7263 in 2017), in other words, $17 \%$ higher than the average of the previous 10 years.

We should point out that, in relation to all Brazilian indigenous territories, not only those in the Amazonian biome, the impact of fires increased by $87 \%$ in 2019, in comparison with those recorded in 2018. In the first years of Bolsonaro's administration, INPE, despite being institutionally fragilized by the administrative changes implemented after the release of data contrary to the official position of the president of the republic, reported 16,680 fires in indigenous territories in comparison with 8,942 fires registered in 2018.

The data presented in the 2020 report about violence against indigenous peoples, published by the Indigenous Missionary Council (CIMI), indicated that in 2019 around 345 indigenous territories were directly or indirectly impacted by the fires in Brazil. The large majority of these, around 272 indigenous territories, were regularized at that moment and thus should have been protected and

\footnotetext{
${ }^{3}$ The information divulged by the National Institute of Spatial Research (INPE) and the Andean Amazon Monitoring Project (MAAP) demonstrate an increase in the rates of deforestation and fires. According to the report presented by MAAP, around 125,000 hectares (approximately 172,000 football fields) have been deforested since the beginning of 2019 and afterwards burned until the peak of fires in August. The majority were identified in the state of Amazonas, of which 39,100 hectares were deforested and afterwards burned. For greater information consult the report available at <https://maaproject.org/2019/amazon-fires-deforestation/>.

${ }^{4}$ Until 22 October 2020, the data provided by the National Institute of Spatial Research (INPE) had registered a substantial increase of 73\%, compared with 2019, with around 89,604 foci of fires in the Amazon region alone.
} 
monitored by the Brazilian state against external threats. However, this did not occur.

The obstacles to the judicial security of the recognition of indigenous territories have become another latent problem. Combined with these factors numerous aspects revealed the socio-environmental vulnerability of indigenous territories in the Amazon region, among those marked by the historic threats of socio-environmental conflicts which put at risk the right to live and remain in their territories.

We understand that these conflicts also reveal the inequalities of political and economic capital, which in the Amazonian case is historically represented by disputes of power in the legislature and the executive - reflexes of the historic traditionalism of oligarchical and patrimonialist political systems - over territorial demarcation policies, as well as over the strategies deliberately used by the government in interests committed to agribusiness which highlight the situation of indigenous peoples and the vulnerability of their territories.

One of the most recent examples is the institutional dismantling of the Ministry of the Environment and its policies. Eloquent evidence of this was expressed by the current minister Ricardo Salles who stated, in a presidential meeting divulged by the Brazilian media, that the current period of crisis in public health caused by the Covid-19 pandemic would be the ideal moment to let 'the cattle herd pass', in other words to pass 'infra-legal' reforms, as well as commencing the 'simplification' of the deregulation of environmental legislation which would favor interested economic sectors and supporters of the current government and who are also directly responsible for the occurrence of deforestation, conflicts, and fires in 'Amazônia Legal'.

Among the deconstructions underway are the increased precariousness of environmental monitoring, including the dismissal of public employees who act in operations against illegal mining (garimpos) in indigenous territories, the censoring of information about deforestation, as well as the alteration of the normative instructions of the Brazilian Institute of the Environment and Natural Renewable Resources (IBAMA) published between March and April 2020, including the authorization of the regularization of rural properties in indigenous territories, 
permitting the exploration and commercialization in territories which have not gone through the formal process of recognition (ratification) ${ }^{5}$.

The results of this strategy are reinforced by experience with 'grilagem' (illegal land appropriation), deforestation, and more recently, the discussion of the regularization of illegally occupied lands covered by Bill no. 2633/20206, or the discussion of Bill no. 191/20207 currently going through the Chamber of Deputies, which proposes the establishment of specific conditions for research and mining of mineral and hydrocarbon resources in indigenous lands, though the latter is still waiting for the creation of a special commission in the federal chamber of deputies.

Recently, we can also highlight two political measures of the current Bolsonaro government that try to weaken the capacity of political organization and the way of life of indigenous peoples. The first was Resolution 04, of January 22, $2021^{8}$, which established 'new criteria for the hetero-identification of indigenous people in Brazil'. It means that the Brazilian State, through its responsible institution (FUNAI), has the prerogative to define in its specific legislation who can be considered indigenous or not. This arbitrary measure aims to cancel the debate on the current processes of ethnic mobilization for the demarcation of self-declared indigenous territories which, in addition to being unconstitutional and violating the legislation established by Convention 169 on indigenous and tribal peoples of the International Labor Organization (OIT) to which the Brazil is a signatory, reveals interests with Brazilian agribusiness. On the other hand, it also establishes a policy of institutional racism based on inadequate criteria widely criticized by contemporary anthropology.

The second is the officialization of Normative Instruction $01 / 2021$ of February 22, $2021^{9}$ that authorizes the establishment of 'partnerships' between indigenous and non-indigenous people for the economic exploitation of indigenous

\footnotetext{
${ }^{5}$ See <https://www.in.gov.br/en/web/dou/-/instrucao-normativa-n-9-de-20-de-marcode-2020-249243190>.

${ }^{6}$ See <https://www.camara.leg.br/proposicoesWeb/fichadetratamitacao?idProposição=2252589>. ${ }^{7}$ See $<$ https://www.camara.leg.br/proposicoesWeb/fichadetramitacao?idProposicao=2236765>. ${ }^{8}$ See <https://pesquisa.in.gov.br/imprensa/jsp/visualiza/index.jsp?data $=26 / 01 / 2021 \&$ jornal $=515 \&$ pagina $=58>$.

${ }^{9}$ See <https://www.in.gov.br/en/web/dou/-/instrucao-normativa-conjunta-n-1-de-22de-fevereiro-de-2021-304921201>.
} 
territories. In addition to bringing legal uncertainty to indigenous peoples, this normative instruction (jointly created by FUNAI and IBAMA) reveals a threat to indigenous peoples' right to exclusive use of territories, it also establishes legislation that will allow, for example, the absence of environmental licensing, the presence of external economic agents and with high political influence in indigenous communities. These policies may increase socio-environmental conflicts and the violation of human rights against indigenous peoples.

The evolution of this scenario also reveals a process of political articulation of interest groups in the Chamber of Deputies and the Brazilian Congress of a whole, the majority of which are either representatives of the traditional patrimonialist oligarchy, or of new fronts of the commercial expansion of the Brazilian business class. The historic organization of these groups in 'bancadas' (interest groups or caucuses), ${ }^{10}$ reveals a more complex process which in the first decades of the twenty-first century has intensified, coming to have protagonism in votes on bills at a national level. In a recent study of environmental policy in the Jair Bolsonaro administration, Araújo (2020) highlights, for example, the clash in congress between the action of the groups linked to the government, and their successive strategies to institutionally weaken sectors linked to the environment, actions of the environmental parliamentary front and social movements, which came to form a defensive coalition against the destruction of environmental protection.

Although they can be understood as a traditional political mechanism of the Brazilian representative democracy system, the 'bancadas' came to have greater expression in the twenty-first century with their interconnection at the level of economic and ideological interests. In this way, they reveal, for example, the stratified interests of commercial sectors which, consequently, impact on

\footnotetext{
${ }^{10}$ Currently, the federal Chamber of Deputies, responsible for the presentation and voting for proposals in the national legislation has a configuration expressed in 11 groups linked to various sectors of interest, becoming more important than those of the national economy, with these 'bancadas' or groups being: 01. Contractors and Construction Companies; 02. Evangelicals; 03. Agriculture (known as 'ruralistas'); 04. Pro-Gun groups (the so-called 'bancada da bala'); 05. Trade union representatives; 06. Human rights; 07. Mining; 08. Commercial/business; 09. Sport; 10. Health, and 11. Political Relatives (the 'parentes' group).
} 
the political and socio-environmental life of indigenous peoples in Brazil, resulting in numerous forms of violence.

\section{Violence, illegalities, and socio-environmental conflict in the Bolsonaro} administration

The transfiguration of violence, when observing the micronational scenario, reveals the inefficiency of the criminal justice system and the irresponsibility of the Brazilian state reflected, for example, in the impunity of cases of murders linked to environmental conflicts. This allows us understand the collusion of current state policies expressed in a deliberate absence of decision making which has an impact on the protection of the territories of indigenous people in the Amazon and in their physical integrity.

Pressure on ecosystems in indigenous territories is marked by an intensification of economic activities predominantly arising out of networks which reinforce the practices of illicit markets. The invasion of communitarian lakes used for fishing, the illegal extraction of gold, the commercialization of timber taken from indigenous lands, and the narcotraffic networks which coerce indigenous peoples, subjecting them to violence, although in an invisible manner, are significant elements for the understanding of an exclusive economic dynamic in contexts of high socio-economic vulnerability.

These illegal markets and transnational networks present in the Brazilian Amazon has allowed the establishment of strategic routes which, although they are recognized and duly mapped, are in constant modification and move a relatively autonomous and functional commercial capital sector, free from the monitoring and inspection of environmental organisms and public institutional security, worsening even more the atmosphere of insecurity in the indigenous territories.

Marginalization, expressed in the statistics of violence in 'Amazônia Legal', evidences the attacks suffered by indigenous peoples and reveal a constant restriction of their right to exist. This practice of the restriction of rights propelled by the state has been increasingly institutionalized in governmental policies currently promoted by the extreme right, with the aim of demobilizing, delegitimating, and not recognizing the right to the use of indigenous territories, as well as their struggles and processes of collective organization. 
In addition, they also have an impact on the production and reproduction of exclusion, isolation, and segregation experienced in the different forms of violence, including the violence institutionalized by the 'necropolitics' of the 'state of exception'. Although they are categories thought of based on situations of war in states of political crisis, Mbembe (2003) and Agamben (2004) reveal a reflection on the options of a 'politics of death' marked by negligence, neglect, and contempt for subalternized and violated minorities, in the last instance, and the discarding of life which does not serve the state.

The data presented in the last report of the international monitoring organization Global Witness on violence in the rural world, (2019), related to the murder of environmental activists and leaders in the world, reveals that Brazil is among the countries with the most deaths resulting from conflicts ${ }^{11}$, above all those related to agri-business, land speculation, and mineral extraction ventures.

In general, the studies also shows that around $80 \%$ of these murders in Brazil occurred in the Amazon region, evidencing that the reality marked by the uncertainties of protection of physical integrity, combined with incipient inspection and the fragile public security policy for social leaders in the Amazon region, are responsible for the high levels of violence in the rural world.

In the Brazilian case, some of the numbers presented by the Dom Tomás Balduino Documentation Center of the Pastoral Land Commission (CPT) confirm this tendency, as it currently registers the highest number of murders of indigenous leaders in the last eleven years. Compared to previous governments, another significant element can be found in the fact that, among the indigenous people murdered in conflicts in the countryside in 2019, the majority of victims were communitarian leaders (CPT, 2020). In addition, the report demonstrates that in 2019 violence in the countryside increased in relation to 2018: the data shows an increase of $14 \%$ in the number of murders, as well as $7 \%$ in attempted murders, and 22\% in death threats, which rose from 165 to 201 cases.

Comparatively, during the Luís Inácio Lula da Silva and Dilma Rousseff administrations, marked by violent conflicts in processes of ethnic mobilization in

${ }^{11}$ Global Witness (2019). Enemies of the state? How governments and business silence land and environmental defenders. Londres: Global Witness. 
favor of rights of territorial demarcation, statistics about the murder of indigenous people throughout the country remained at an annual average of 52 deaths, in accordance with the reports on violence against indigenous people published by CIMI between 2003 and 201512. In the Michel Temer and Jair Bolsonaro administrations, the figures are greater in a short period of time and just in relation to the states of the Brazilian Amazon.

In this context, the survey made by the Indigenous Missionary Council (CIMI) revealed that murders have become more evident in comparison with recent years. As shown in Figure 01, Amazonas and more especially Roraima stand out as the states with the highest number of events.

Figure 01. Indigenous people murdered between 2018 and 2019 in 'Amazônia Legal'* $^{*}$

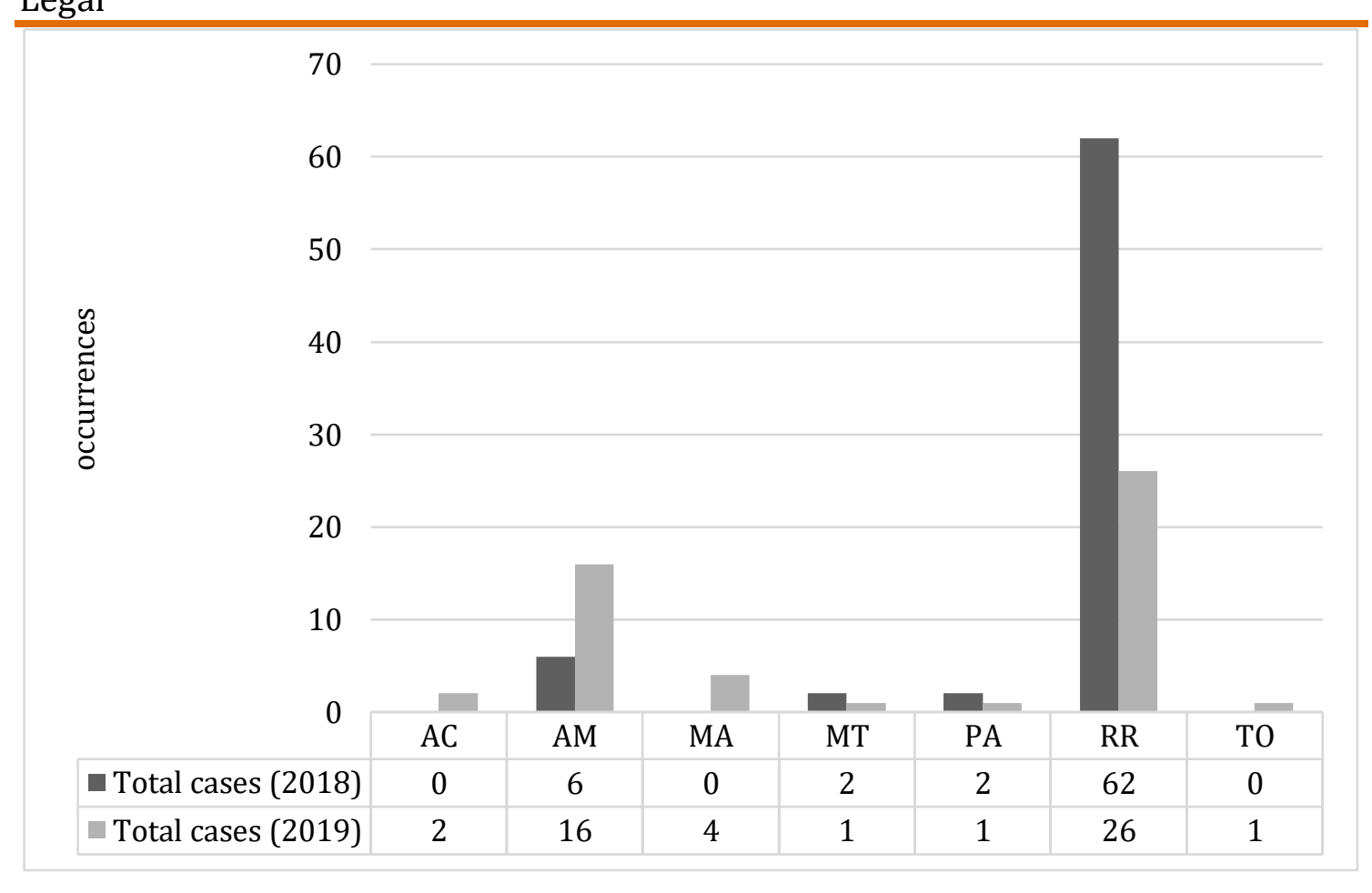

Source: Prepared by the author based on the Indigenous Missionary Council $(2020,2019)$.

Note: *Amapá and Rondônia are part of 'Amazônia Legal', but they are not contained in the figures due to the lack of official information.

The expression of these conflicts in many cases is configured by the condition of use of the territory. In the case of indigenous peoples in 'Amazônia Legal' insecurity and violence also reveal that the attacks on material and immaterial

${ }^{12}$ See <https://cimi.org.br/observatorio-da-violencia/>. 
patrimony in traditionally occupied territories ${ }^{13}$. In the majority of cases, conflicts occur through distinct forms of occupation of spaces and due to the advance of agribusiness in lands which, even though they are recognized as being for the use of indigenous peoples, still suffer from a delay in regularization by competent institutions and the lack of inspection and public security (Figure 02).

Figure 02. Violence against the patrimony of indigenous territories

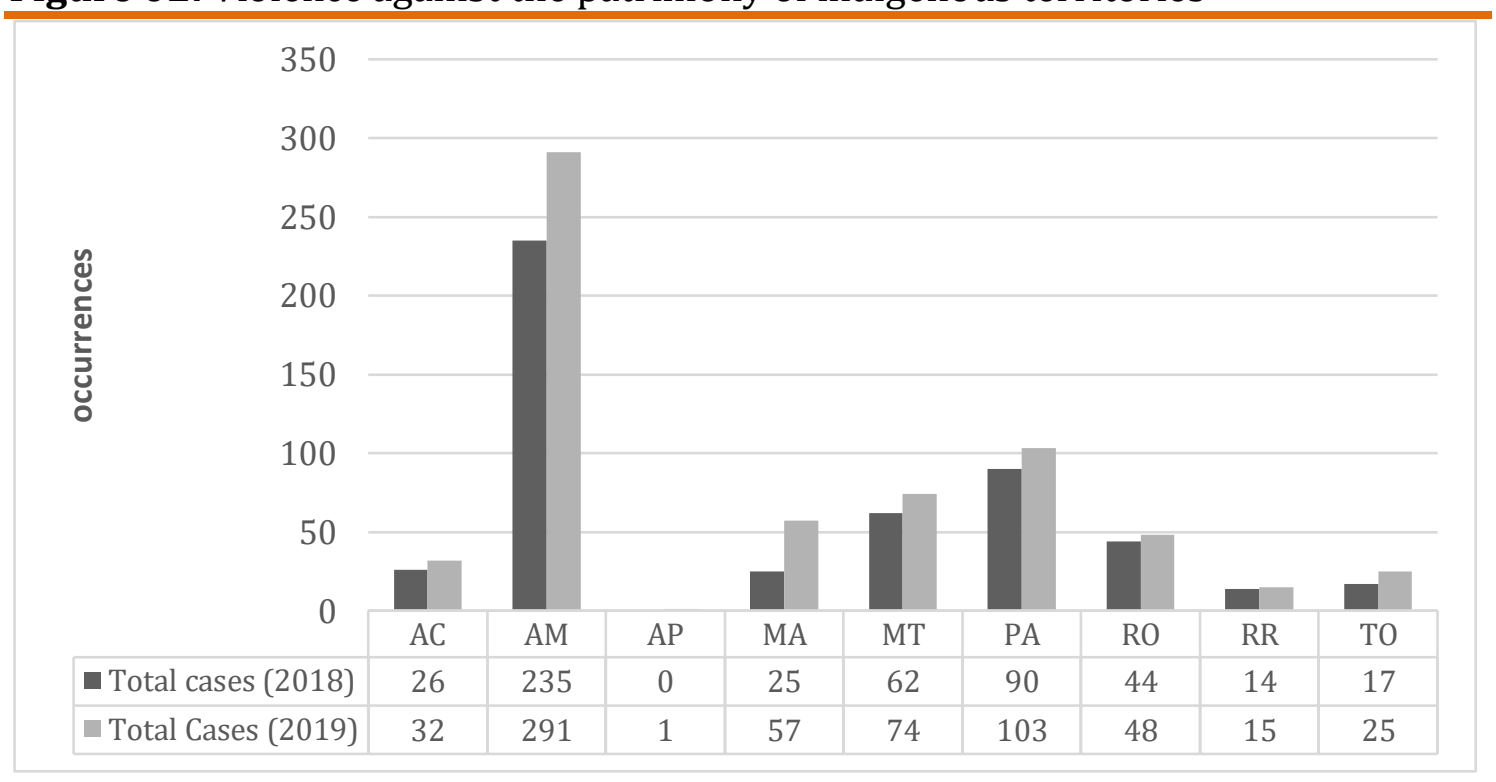

Source: Prepared by the author based on the Missionary Indigenous Council $(2020,2019)$.

Situations of confrontation and violence are not only restricted to attacks on the patrimony of indigenous peoples, in general characterized by the use of the territory occupied and the buildings constructed (houses, 'roças', communitarian spaces), but also contemplate the increase, in recent years, of multiple forms of violence against people, caused by factors which are not linked just to the territory. Among the examples highlighted in the data provided by public institutions in the states of 'Amazônia Legal' and organized by the Indigenous Missionary Council (CIMI) are numerous types of violence configured in a complex manner in indigenous territories (Figure 03).

According to the report on violence against indigenous people published by CIMI (2020), the events reported in Figure 03 generally involved situations in which

\footnotetext{
${ }^{13}$ The category of traditionally occupied lands is understood as something more than its normative judicial perspective (VIEGAS, 2017), as an indispensable territory for the maintenance of activities which allow the material and symbolic reproduction of collective life.
} 
there occur 01. Abuse of power; 02. Death threats; 03. Various threats; 04. Manslaughter; 05. Willful bodily injuries; 06. Ethnic and cultural racism and discrimination; 07. Attempted murder; and 08. Sexual violence. The increase in cases in states such as Acre, Amazonas, and Maranhão is due to the climate of impunity combined with the lack of public security policies which can reinforce the protection of the physical integrity of indigenous peoples, above all in regions of difficult logistical access. Also deserving of mention is the difficulty of access to official data, flagrant in the absence of information made available by the state of Amapá. The invisibility of cases derived from sub-notification or the absence of the official registration can also be revealed as a type of violence.

Figure 03. Violence against indigenous people

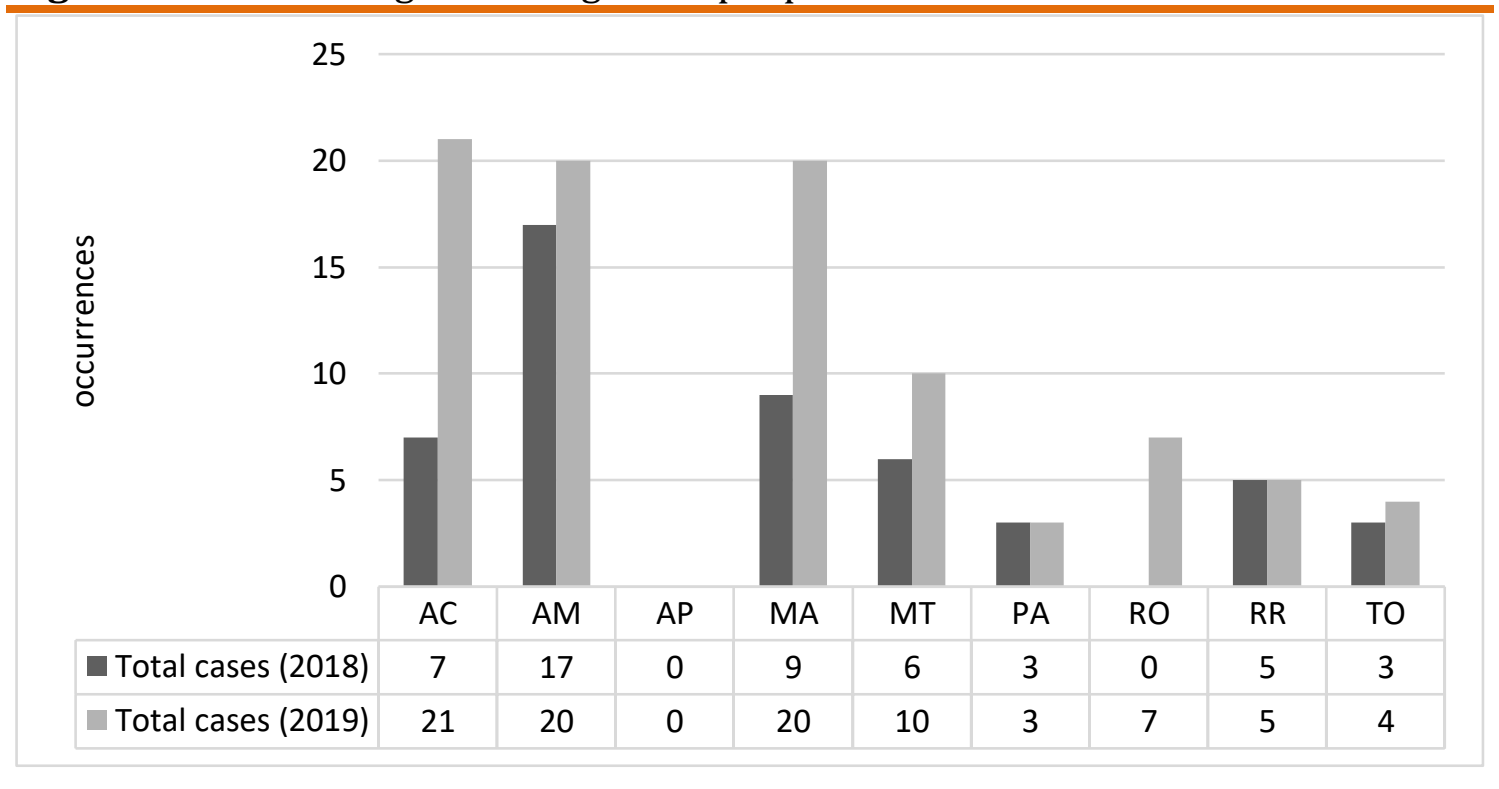

Source: Prepared by the author based on the Missionary Indigenous Council $(2020,2019)$.

Violence in this historical context of governmental transition (Michel Temer - Jair Bolsonaro) in a moment of political reconfiguration, which favored the rise of conservative movements in defense of private property and 'latifúndio', came to adopt indigenous peoples as the nearest enemy. Judicial insecurity in the indigenous territories of 'Amazônia Legal' reveals a latent problem marked by the need for quicker solutions, since the lack of measures about formal recognition, through ratification by the competent institutions, have become a serious obstacle in the Bolsonaro administrations. 
The National Indian Foundation (FUNAI), linked to the Ministry of Justice, is responsible for the process of the formal recognition of indigenous territories. It involves various stages according to Decree 1.775, dated 08 January 1996, which provides for the administrative procedure of the demarcation of indigenous areas.

Among the procedures in questions are: 01. anthropological, historical, land, cartographic, and environmental studies, which justify the identification and delimitation of indigenous lands; 02 . the delimitation of territories for which the relevant studies were approved by the Presidency of FUNAI and whose completion has been notified in the 'Diário Oficial da União' or state equivalents, and which are in the phase of administrative adversarial procedures or being analyzed by the Ministry of Justice, before a decision is taken about the issuing of the Declaratory Edict of traditional indigenous possession of the land in question; 03. the process of the declaration of lands for which the Declaratory Edict has been issued by the Ministry of Justice and are authorized to be physically demarcated, with the materialization of landmarks and geo-referencing; 04. the ratification of territories whose boundaries have been materialized and geo-referenced whose administrative demarcation was ratified by Presidential decree; and 05 . the regularization of land which, after the ratification decree, has been registered in a Notary Office in the name of the Federal Union and the Secretariat of Federal Assets.

However, we know that part of the bureaucratic delay in relation to the process of regularization of indigenous territories is historical and results from previous administrations which in the last decade came to restrict with greater frequency the ratification of indigenous lands. More recent data indicates the elevated number of pending situations without any type of measures being taken by the government, as highlighted by Figure 04 .

Political reconfiguration in the federal sphere has prevented the processes begun between the presidency of Michel Temer and the current administration of the Bolsonaro government from making progress. In this context, FUNAI came to be administered by sectors representing interests linked to agri-business, while the defenders of policies for the expansion of agricultural frontiers 
represented in the Chamber of Deputies by the 'bancada ruralista' and the mining lobby hindered this process, equally supported by the presidency of the republic ${ }^{14}$.

Figure 04. Situation of regularization of indigenous territories in 'Amazônia Legal'

\begin{tabular}{|c|c|c|c|c|c|c|c|c|c|}
\hline \multicolumn{10}{|l|}{250} \\
\hline \multicolumn{10}{|l|}{200} \\
\hline \multicolumn{10}{|l|}{150} \\
\hline \multicolumn{10}{|l|}{100} \\
\hline \multicolumn{10}{|l|}{50} \\
\hline 0 & $-{ }_{A C}$ & In & $\mathrm{AP}$ & $\overline{M A}$ & L = & $-{ }_{-1}$ & RO & $\mathrm{RR}$ & $\mathrm{TO}$ \\
\hline To be identified & 8 & 15 & 0 & 3 & 15 & 24 & 3 & 0 & 3 \\
\hline Declared & 2 & 12 & 0 & 1 & 6 & 5 & 1 & 0 & 2 \\
\hline Approved & 1 & 3 & 0 & 0 & 1 & 3 & 0 & 0 & 0 \\
\hline Identified & 0 & 2 & 0 & 2 & 7 & 4 & 0 & 0 & 0 \\
\hline Restriction Ordinance & 1 & 1 & 0 & 0 & 1 & 1 & 1 & 1 & 0 \\
\hline No government action & 7 & 197 & 0 & 7 & 22 & 29 & 22 & 2 & 4 \\
\hline - Total & 19 & 230 & 0 & 13 & 52 & 65 & 27 & 3 & 9 \\
\hline
\end{tabular}

Source: Prepared by the author based on the Missionary Indigenous Council $(2020,2019)$.

In this way, like the other public agencies that are strategic for the territorial administration of the Amazon Region, FUNAI ended up being weakened by the reduction of fundamental resources for monitoring, inspection, and other social actions carried out by its regional coordination bodies. This blatant dismantling has led the government to hold legally responsible public employees who oppose the agency's policies and its current position of being aligned with external interests, as well as the expressive precariousness of the work situations of these public employees who work with indigenous peoples. The slowness of these processes has consequently caused various problems which extend to the numerous realities and particularities of various ethnic groups, due to the form of use, and the relationship each one maintains with their territories.

\footnotetext{
${ }^{14}$ In the 2018 presidential campaign, the current president Jair Bolsonaro publicly stated that on being elected he would not demarcate one centimeter of land for indigenous peoples during his administration. (See <https://epoca.globo.com/expresso/nao-demarcarei-um-centimetro-quadradomais-de-terra-indigena-diz-bolsonaro-23300890>).
} 
Institutional violence and the omission of the government: expressions of public administration in times of pandemic

The inefficiency and absence of state policies also reveal another face of the violence which impacts on indigenous peoples. Lack of commitment to the public provision of essential services in territories in situations of socio-economic vulnerability expressed an institutional violence which is not only resumed in socioenvironmental conflicts, but also in the omission of public power which in many cases have become the target of legal cases taken by the 'Ministério Público Federal' (Federal Prosecution Service).

The violation of constitutional rights, affected by the fragilities of social assistance/welfare policies, as represented by Figure 05, which reveals situations such as: 01. General lack of assistance; 02. Lack of assistance in the area of indigenous education; 03. Lack of assistance in the area of health; 04. Absence of policies against the dissemination of alcoholic and other drugs; as well as cases of 05. Death due to the lack of assistance for health in difficult to access areas.

\section{Figure 5. Violence caused by the omission of the government}

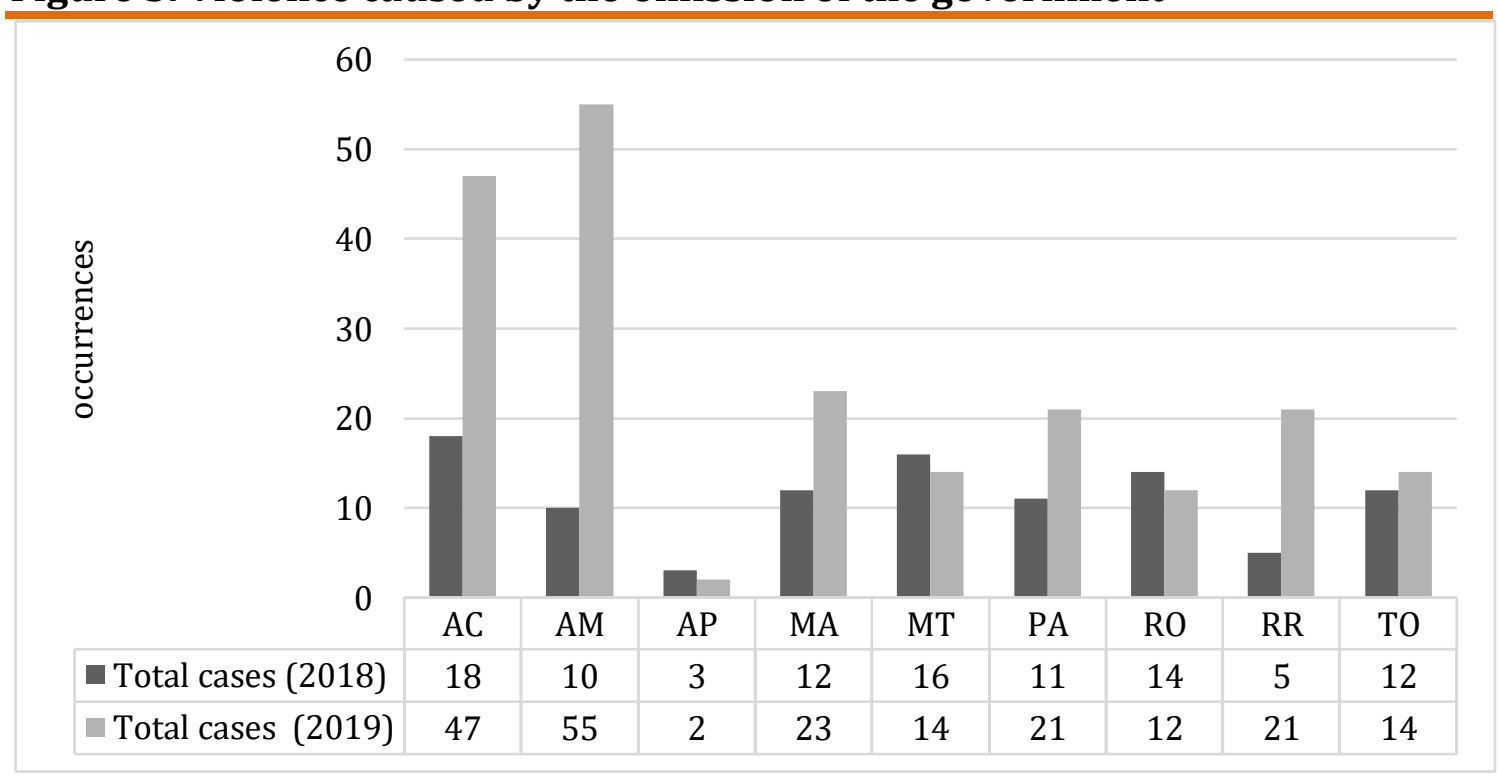

Source: Prepared by the author based on the Missionary Indigenous Council $(2020,2019)$.

Another data of concern is related to rising rates of child mortality and selfinflicted violence through suicide in the states of 'Amazônia Legal', which points to a serious flaw in the extension of public health care (Figure 06).

$$
\text { (2021) } 15(2) \quad \text { e0002-16/25 }
$$


Indigenous child mortality expressed in the statistics of public institutions reveals a concerning scenario in states such as Amazonas, where difficulties of access is also due to numerous problems faced in indigenous territories with the absence of specialized professionals in the accompanying of pregnancy, pediatrics, and social assistance in difficult to access places.

In general, the data from Figure 06 is explained by the fragility of institutional support for workers specialized in indigenous health which, in situations of precariousness and compromised by the complex logistics of movement in the majority of indigenous territories, find themselves impossible to implement in a more effective manner actions compatible with regional reality.

Figure 06. Indigenous child mortality in the states of 'Amazônia Legal'

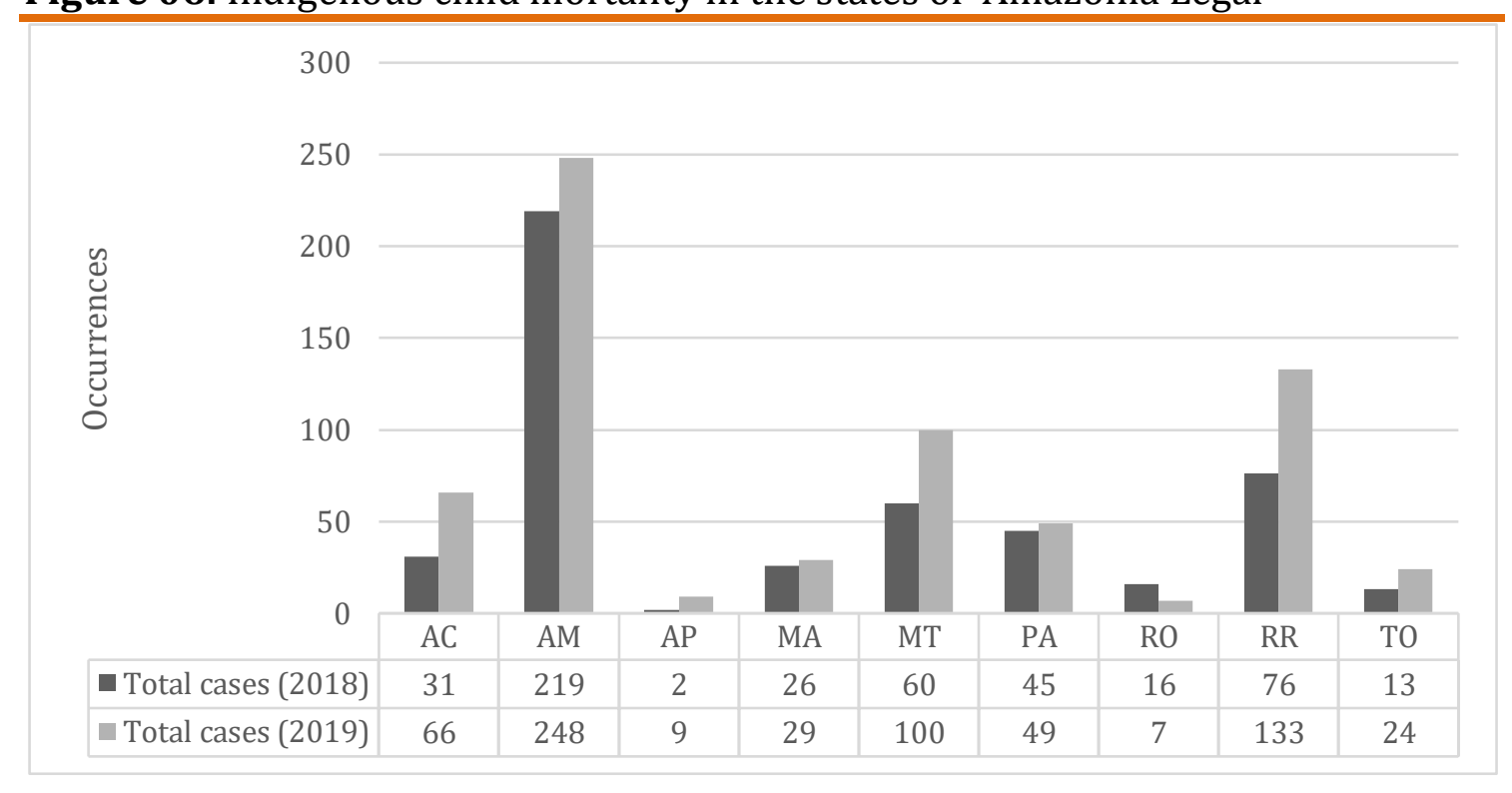

Source: Prepared by the author based on the Missionary Indigenous Council $(2020,2019)$.

The dismantling of the sectors of health and provision of care to indigenous peoples is related to the problem of budgets that are increasingly related to the problem of increasingly scarce budgets and also the earmarking of funds that are no longer used in providing care and basic prevention to health. In indigenous communities where there is no type of legal recognition or measures on the part of the state (ratification, regularization, or state of demarcation), the situations tend to worsen while the actions of the Special Indigenous Health District (DSEIS) are in general restricted to legally recognized lands. 
Another situation in the field of public health which also represents a threat to indigenous peoples is in the occurrence of suicide which, in recent years, has become an element of discussion in the field of indigenous health care policies. Although numerous factors can lead to self-inflicted violence, it is a recurrent chronic and complex problem, which should be considered in light of the different ethnic groups. However, the fragility of actions by the public authorities to establish measures of prevention and education against self-inflicted violence has been preoccupying, above all in territories where the presence of the state is partial or absence, which hinders still more formal notifications.

In Figure 07 it is possible to note that the states of Amazonas and Roraima have a significant number of cases of suicide, although it can be considered that the results obtained are due to greater state capacity to register this information, which significantly indicates that the other states have a problem of sub-notification.

Figure 07. Occurrence of Suicides among the Indigenous Peoples in 'Amazônia Legal'

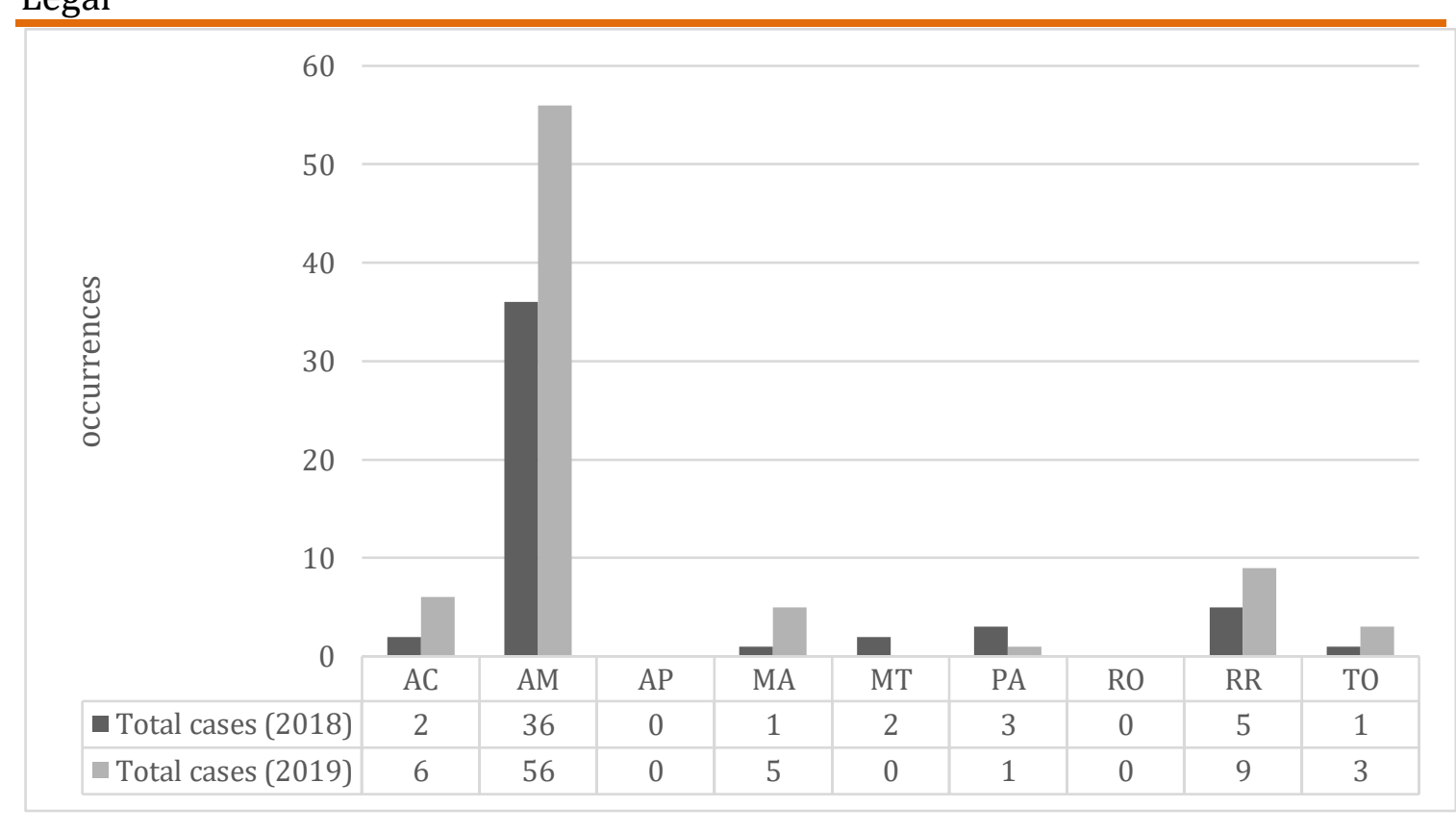

Source: Prepared by the author based on the Missionary Indigenous Council $(2020,2019)$.

Rangel (2019) reveals that during the last 20 years, information about suicide was marked by the absence of officially registered cases, which makes more challenging analyses based on the data provided by the Ministry of Health and state and municipal secretariats, although she emphasizes that from 2014 
onwards, there occurred an increase in official notifications in a large part of states. Another aspect revealed in the studies she presents about the data collected officially by public institutions states that between 2000 and 2015 the annual average of suicides between indigenous peoples in Brazilian states was 58; however, between 2016 and 2019 the average jumps to 116 annual deaths.

One of the factors associated with this drama is related to the consumption of alcoholic beverages in indigenous territories. These are acquired in adjacent urban centers and, in some cases, became goods in the control and exploitation of the indigenous labor force in the illegal extraction of natural resources. Chemical dependency is a problem increasing neglected by the state and, in the final instance, it reveals another invisible aspect of violence against indigenous peoples in places ignored by public policies.

In the middle of the current health crisis involving the contamination of the Brazilian population by the new coronavirus (Covid-19), the incapacity of governmental policies expressed in the rates of lethality and deaths registered in the states of 'Amazônia Legal' reveal their most perverse face. The evidence of transmission among indigenous peoples has become concerning, the most recent data presented in January 2021 by the Coordination of Indigenous Organizations of the Brazilian Amazon ${ }^{15}$ (COIAB) estimates 762 suspected cases, 32,399 confirmed cases, and 739 officialized registrations of deaths, not including the numerous deaths resulting from the precariousness of indigenous health care, not counting the sub-notification and the absence of information from hard to access locations.

Another serious element that can increase cases of indigenous mortality is in the criteria established by the Ministry of Health policy for planning the immunization of indigenous peoples against Covid19. With the creation of Normative Instruction $\mathrm{n}^{\circ} 09$ of April 16, 202016, the Bolsonaro government established, at the beginning of the Covid19 pandemic, criteria to analyze the issuing of the declaration of recognition of boundaries of indigenous territories, even threatening the right of possession and historical use of indigenous peoples. This means that a significant part of the indigenous population that currently does not

\footnotetext{
${ }^{15}$ References consulted on 20 November 2020 on the official page of the organization. Available at $<$ https://coiab.org.br/covid>.

${ }^{16}$ See <https://www.in.gov.br/en/web/dou/-/instrucao-normativa-n-9-de-16-deabril-de-2020-253343033>.
} 
inhabit territories legally recognized by the Brazilian State will remain outside the priority groups for immunization against Covid19, such as indigenous people living in urban contexts or in collective territorial occupations. This reality reveals an exclusive and segregationist policy when we talk about the right of access to vaccine against Covid19.

Since the violent colonial process, now put again to the test, indigenous peoples have been able to resist problems external to their way of life. The process of communitarian transmission of Covid-19 in their territories has threatened above all the reproduction of life, to the extent that it puts at risk their rights of existence as autonomous and sovereign peoples, in an expression of institutional violence unleashed by necropolitics.

One of the responses found today to confront the pandemic is based on the experiences of ethnic mobilization and collective solidarity. In the middle of the absence of answers from the federal government to fight the dissemination of Covid-19 in their territories, we can see the numerous and creative support initiatives.

These movements have mobilized organized civil society, popular communitarian organizations, universities, and research groups, revealing alternatives of resistance in the middle of crisis in public health. In the states of 'Amazônia Legal', the organizational capacity and ethnic mobilization of indigenous peoples in the defense of its territories against community transmission of Covid-19 have demonstrated the importance of indigenous protagonism through local experiences along with numerous partnerships.

Supporting actions are presented in numerous forms, such as solidarity cooperation for the raising of financial resources converted into prevention material (hygiene kits), the distribution of food baskets, and the production of preventative communication information, translated into maternal languages, developed with the support of universities and local non-governmental organizations. It is important to highlight the role of higher education institutions, research centers, and other historic partners of indigenous peoples in this regional context, since they are revealed to be crucial in the production of qualified information and in the monitoring of data which helped in the construction of policies aimed at the improvement of quality in their ways of life. 
These initiatives imposed the need to understand the socio-cultural, environmental, and economic particularities of these territories as essential for the maintenance of good living. They also put in question the need to recognize the diversity of conceptions about disease and cure among the indigenous peoples, as well as the emergency adoption of public policies for combat and prevention of their territories, making visible and respecting this knowledge. However, the actions of collective mobilization led by indigenous people throughout the Brazilian Amazon demonstrate that solidarity is a path to resistance and for the production of a socially just world in difficult moments.

\section{Conclusions}

When we speak of the absence of governmental policies committed to indigenous peoples in the current context of the Bolsonaro administration, we do not speak only of the institutional dismantling carried out to the benefit of strategic economic interests, we also talk about an Amazon in crisis in the present, marked by political violence in state acts, the illegality of economic activities expressed in the contradictions of planned development models for this region, since this reveals the evident marginalization in statistics which are reproduced in a scenario of vulnerability, exclusion, and territorial, social, and political segregation.

Socio-environmental impacts historically experienced in the daily life of indigenous peoples in this and in previous governments have evidenced the fallibility of public policies in providing attention, care, and prevention against any movements which threaten life in the Amazon region, in its most complex sense.

Furthermore, socio-environmental conflicts and the institutionalization of violence in its multiple forms of existence represent a frontier of denying the right of indigenous peoples to exist. Their daily limits and risks impose challenges marked by a field of unequal and exclusive struggle in the Brazilian Amazon.

This materially evident phenomenon is presented as an expression of the violation of human rights in the middle of the unequal dispute of economic, political, and social capital, sponsored by an expression of necropolitics occurring in Brazil at present. Attacks on the rights of traditional peoples and communities are based on, 
amongst other preconditions and factors, interests and forms of exploitation of nature which in the last instance trigger the expressions of violence presented here.

Furthermore, the economic strategies and interests involved in the Brazilian Amazon in the second decade of this century are associated with the rise of political conservativism and groups (bancadas), in part responsible for the patrimonialist oligarchies which have historically occupied a place in prestige in Brazilian economics and politics.

Divergent forms of appropriation of nature have expressed an unchecked expansion of economic activities, and even illegal networks of commerce, with distinct particularities given the involvements of interested agents. In addition to the typification of forms of conflict materialized in violence, they also reflect the impotence of local institutions, above all because it involves extensive territories where the 'non-existence of the state' and its governmental policies is evident.

The maintenance of the scenario of violence in Amazon in recent decades, as well as revealing the disputes over access to the use of land, becomes even more complex during the period which runs from the institutional coup which resulting in Michel Temer becoming president, to the neo-fascist and conservative ascension, representative of an ultraliberal economy, and to the current Brazilian president Jair Bolsonaro.

The notion of a state of exception, here considered under the perspective of the current government, reveals, according to Agamben (2004), the negation of law and popular sovereignty in an assault on democracy, in a diagnosis which understands that 'exception is the absolutism of contemporaneity', or also an expression of the judicial forms of neoliberalism (VALIM, 2017). Moreover, the exception also expresses the process of the depoliticization of society and the transformation of democratic dialogue in an authoritarian, subordinated to economic policies.

In addition, the impossibility of conflict resolution not only reflects judicial insecurity and the improbable guarantee of territorial rights aimed at indigenous peoples, but also makes explicit a policy of death, exception, and the violation of rights. These events increasingly impose the necessity among the indigenous peoples of an emancipatory political project against all forms of violence, exclusion, inequality, and the death of culture and knowledge. This process is now presented 
in the Brazilian Amazon in many joint experiences and aspects, constructed with various agents, but with the protagonism of the political and ethnic mobilization of indigenous peoples in the process of resisting and existing.

Translated by Eoin Portela Submitted on January 21, 2021 Accepted on February 05, 2021

\section{References}

ADORNO, Sérgio (1999), Violência e civilização. In: A sociologia para o século XXI. Edited by SANTOS, José Vicente Tavares dos and GUGLIANO, Alfredo Alejandro. Pelotas: EDUCAT. pp. 77-106.

AGAMBEN, Giorgio (2004), Estado de exceção: Homo Sacer, II, I. São Paulo: Ed. Boitempo. 144 pp..

ARAÚJO, Suely Mara Vaz Guimarães de (2020), Environmental policy in the Bolsonaro government: the response of environmentalists in the Legislative Arena. Brazilian Political Science Review. Vol. 14, № 02, pp. 01-20.

BARREIRA, César (2008), Cotidiano despedaçado: cenas de uma violência difusa, Campinas: Ponte Editores. 262 pp..

BECKER, Bertha K. (2004), A Amazônia e a política ambiental brasileira. GEOgrafia. Vol. 06, № 11, pp. 07-20.

BOURDIEU, Pierre (2014), Sobre o Estado: cursos no Collège de France (1989-92). São Paulo: Companhia das Letras. 610 pp..

BOURDIEU, Pierre (1989), o poder simbólico: memória e sociedade. Lisboa: Difel. 159 pp..

COMISSÃO PASTORAL DA TERRA (2020), Conflitos no campo: Brasil 2019. Goiânia: CPT Nacional. 252 pp..

CONSELHO INDIGENISTA MISSIONÁRIO (CIMI) (2020), Violência contra os povos indígenas no Brasil - Dados de 2019. Brasília: CIMI. Conferência Nacional dos Bispos do Brasil (CNBB). 216 pp..

CONSELHO INDIGENISTA MISSIONÁRIO (CIMI) (2019), Violência contra os povos indígenas no Brasil - Dados de 2018. Brasília: CIMI. Conferência Nacional dos Bispos do Brasil (CNBB). 156 pp..

ELIAS, Norbert and SCOTSON, John L. (1965), The established and the outsiders: a sociological enquiry into community problems. London: F. Cass. 252 pp.. 
GIDDENS, Anthony and HELD, David (1982), Classes, power and conflict: classical and contemporary debates. London: MacMillan. 640 pp..

GLOBAL WITNESS (2019), Enemies of the state? How governments and business silence land and environmental defenders. London: Global Witness. 52 pp..

HAWKINS, Darnell F. (ed)(1995), Ethnicity, race, and crime: a review of selected studies. In: Ethnicity, race, and crime: perspectives across time and place. New York: State University of New York Press. pp. 11-45.

IANNI, Octávio (2004), Capitalismo, violência e terrorismo. Rio de Janeiro: Civilização Brasileira. 381 pp..

IANNI, Octávio (1979), Ditadura e agricultura: o desenvolvimento do capitalismo na Amazônia 1964-1968. Rio de Janeiro: Civilização Brasileira. 249 pp..

INSTITUTO NACIONAL DE PESQUISAS ESPACIAIS (INPE)(2019), Alertas do DETER na Amazônia em junho somam 2.072,03 $\mathrm{km}^{2}$. Available at

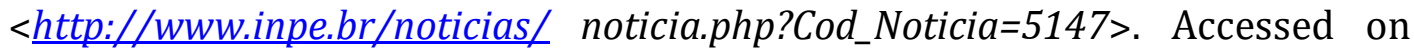
July, 04, 2019.

MACHADO, Helena (2008), Manual de sociologia do crime. Porto: Edições Afrontamento. 128 pp..

MARTINS, Heloísa Helena T. de Souza (2004), Metodologia qualitativa de pesquisa. Educação e Pesquisa. Vol. 30, № 02, pp. 289- 300.

MBEMBE, Joseph-Achille (2003), Necropolitics. Public Culture. Vol. 15, № 01, pp. 11 40.

MISSE, Michel (2006), Crime e violência no Brasil contemporâneo: estudos de sociologia do crime e da violência urbana. Rio de Janeiro: Lumen Juris. 300 pp..

PICOLI, Fiorelo (2006), O capital e a devastação da Amazônia. São Paulo:Expressão Popular. $256 \mathrm{pp}$.

RANGEL, Lucia, Helena (2019), Violência autoinfligida: jovens indígenas e os enigmas do suicídio. Densidades. № 25, pp. 27-38.

RAPOZO, Pedro and SILVA, Manuel Carlos (2020), Fronteiras da re-existência e resistência: as cartografias dos conflitos socioambientais na tríplice fronteira amazônica, Colômbia e Peru. Configurações. Vol. 25, № 01, pp. 59-87.

SANTOS, José Vicente Tavares dos (2009), Violências e conflitualidades. Porto Alegre: Tomo Editorial. 176 pp..

VALIM, Rafael (2017), Estado de exceção: a forma jurídica do neoliberalismo. São Paulo: Editora Contracorrente. 64 pp.. 
besr a Pedro Rapozo

VIEGAS, Daniel Pinheiro (2017), A tradicionalidade da ocupação indígena e a constituição de 1988: a territorialização como instituto jurídico-constitucional. Manaus: UEA Edições. 256 pp..

WACQUANT, Loïc (2000), As prisões da miséria. Lisboa: Celta Editora. 170 pp.. 